\title{
CHARACTERISTIC FEATURES OF PROJECT MANAGEMENT IN SMALL AND MEDIUM-SIZED ENTERPRISES
}

\author{
Remigiusz Kozlowski, Marek Matejun
}

\section{Introduction}

The operation and growth of small and mediumsized enterprises (SMEs - including micro enterprises) are significantly determined by the characteristic features and internal diversity of this group of entities (Torrès \& Julien, 2005; Curran, 2006). The identification of characteristic properties leads to a qualitative and quantitative distinction between small and medium-sized companies from other entities, primarily including large enterprises (LEs) (Marchesnay, 1982; Bannier \& Zahn, 2012). This set of properties, or "SME Ordinaire" as proposed by Reboud, Mazzarol, and Clark (2011) - concerns, e.g., general managerial characteristics, organizational configuration, strategy and market orientation. It is manifested by a less structured and formalized approach to management practice, survival, and business development (Geroski, 1999).

The search for functional characteristics, which is connected with SME activity in various areas of management, is another important direction for research. One such area of growing importance for today's organizations is project management. The approach is businesses' way of coping with the increasing scope, complexity, dynamics, and uncertainty of the environment. These circumstances create many new challenges for modern enterprises (Mcgrath \& Macmillan, 2009) and significantly affect the operation of SMEs (West \& Drnevich, 2010). Using project management ensures the high flexibility and efficient rationality of action. However, project management should be implemented with consideration for the individual needs and possibilities of specific business entities, including SMEs.

Considering this, the paper aims to identify and evaluate select areas related to the qualitative characteristics of project management in SMEs. The analysis concerns particular phases in a project life cycle and is based on the results of research conducted on a sample of $\mathrm{N}=897$ enterprises, including $\mathrm{n}=563$ SMEs, and $n=334$ LEs. The test of the difference between two population proportions was used to identify the areas of project management characteristic to SMEs statistically.

\section{Theoretical Background and Hypotheses}

Academic publication that takes the characteristic features of small and mediumsized enterprises into account has historically originated from research developed on the management of these entities (Torrès, 2003). The beginning of this trend is linked to the studies of the Aston school of thought (Pugh, Hickson, Hinings \& Turner, 1968; Pugh, Hickson \& Hinings, 1969) and concerns the influence of enterprise size on its structure and operation (Penrose, 1959; Mintzberg, 1979). Within the trend of specificity (Dandridge, 1979), SMEs are treated as a coherent group in opposition to LEs. Their characteristics may be of a qualitative or quantitative nature.

In their analysis of qualitative characteristics, Blili and Raymond (1993) classify the characteristic features of SMEs into five sets: (1) environmental features, (2) organizational features, (3) decisional features, (4) psychsociological features, and (5) information systems related features. A more elaborate approach is proposed by Nicolescu (2009), who (taking into account internal and external variables) identifies 10 general features of the organizational systems of SMEs: (1) low size and complexity, (2) high typological diversity, (3) intensive human dimension, (4) low degree of formalization, (5) strong interconnection of the formal and informal elements; (6) relative procedural and structural simplicity, (7) high flexibility, (8) strong entrepreneurial 
personalization, (9) intensive decisional centralization, and (10) relatively frequent use of the authoritarian and, respectively, participative approach.

The concept that shifts the considerations closest to the general characteristics of SMEs is the idea of small business as a proximity mix, where Torrès (2004) distinguishes five types of proximity: (1) hierarchical proximity, (2) intrafunctional proximity, (3) proximity information systems, (4) time factor (or temporal) proximity, and (5) spatial proximity. In these models, small and medium-sized businesses are characterized by a strong influence of company owner personality and high sensitivity to changes in external conditions (D'Amboise \& Muldowney, 1988). The management process is dominated by short- and mediumterm perspective and low level of procedure formalization (Barrett \& Mayson, 2007). Planning is used to a limited extent and is often informal (Honig \& Samuelsson, 2012).

On the other hand, small and medium-sized firms are characterized by high flexibility of action (Verdú-Jover, Lloréns-Montes \& GarcíaMorales, 2006; Alpkan, Yilmaz \& Kaya, 2007), relatively high and efficient innovation (Verhees \& Meulenberg, 2004; Terziovski, 2010; Szabo, Šoltés \& Herman, 2013), and well-developed adaptability to the changing environment (Levy \& Powell, 2004).

As far as the quantitative featured of SMEs are concerned, attention is paid to the quantity of resources held (controlled) and the quantifiable size of business. In this case, the features emphasized most are the employment volume, expenditure, and profits of the business.

The conceptual framework of the characterization provides the basis for the definition and identification of small and mediumsized enterprises among all business entities in general. Nevertheless, the aspects adopted for definition purposes are usually of quantitative nature and may differ from country to country (Ayyagari, Beck \& Demirguc-Kunt, 2007). According to a World Bank study, over 125 million formal SMEs operate in 132 countries, including 89 million SMEs in emerging markets (Kushnir, Mirmulstein \& Ramalho, 2010). They perform important economic and social roles, significantly affecting the employment level, creation of new jobs, or GDP (Haltiwanger, Jarmin \& Javier, 2013). According to 2012 data, there are 20.7 million small and medium- sized entities in the EU, accounting for more than $98 \%$ of all enterprises. The SME sector employs over 87 million people $(67 \%$ of total employment) and participates in the generation of $58 \%$ of gross value added (Wymenga, Spanikova, Barker, Konings \& Canton, 2012).

However, as remarked by Curran and Burrows (1993) and Curran and Blackburn (2001), pinpointing the characteristics alone is not enough to clearly define SMEs, due to the diversity and heterogeneity of this group of entities. This leads to the creation of a conceptual framework stressing the high diversity of SMEs. Examples of such an approach include the idea of the denaturation (loss of characteristic features) of SMEs (Torrès, 2003), or the concept of small business antithesis (Torrès \& Julien, 2005). Despite the development of research on the internal diversity of SMEs as a group, the trend in the search for their specific features may be viewed as an established doctrine (Stevenson \& Jarillo, 1990; Gartner, Bird \& Starr, 1992) aspiring to the position of the dominant approach to studies on small-business management.

This is made manifest by the development of research within this cognitive trend, which currently deviates from the general characteristics of SMEs in favor of their functional characteristics connected with specific areas or methods of management. What has emerged as an important research trend here are comparative studies of small and medium-sized companies and large ones. Among other topics, these studies concern intrapreneurship (Carrier, 1994), innovation practice (Koc, 2011; Vahter, Love \& Roper, 2012), and intellectual property protection policy (Fernández-Ribas, 2010). A significant empirical trend is represented by studies on the functions of enterprises, e.g., marketing and logistics (Rawwas \& lyer, 2013), or the application of modern management methods, e.g., the concept of corporate social responsibility (Coppa \& Sriramesh, 2013), or competitive intelligence (Molnár \& Střelka, 2012). Comparative studies also focus on the environment of SMEs and LEs. Examples include the research by Fong, Chen and Luk (2012) concerning location choices, or studies by Walker (2010) on the terms and costs of obtaining short-term credit for small and large firms.

Another major direction for research on the functional characteristics of SMEs is also 
the issue of project management. Project management has become one of the key challenges facing today's organizations, something confirmed both by economic practice and the development of research in this field (Kwak \& Anbari, 2009; Söderlund, 2011; Garel, 2013). Projects, defined as "a onetime activity with a well-defined set of desired end results" (Meredith \& Mantel, 2011, p. 11), which are in contrast to the process approach to management (Tuček, Hájková \& Tučková, 2013), play an important part in a dynamic, complex and uncertain environment, providing a response to accelerated competition, increased economic pressures, and rapid technological change (Patanakul \& Shenhar, 2012). Their use by small and mediumsized businesses enables cost reduction and facilitates the introduction of new products and services to the market (Larson, Gobeli \& Gray, 1991), primarily including innovative solutions in response to individual and changing client requirements (Allocca \& Kessler, 2006).

The idea of project-based management fits well with the qualitative characteristics of SMEs, as its use required the development of dynamic capabilities allowing enterprises to react effectively to changes occurring in a competitive environment (Teece, Pisano \& Shuen, 1997; Teece, 2007). On the other hand, project management requires the involvement of specific resources (Mathur, Jugdev \& Fung, 2007; Jugdev \& Mathur, 2012). Due to resource shortages and other qualitative properties, that project management in SMEs would display specific characteristics different from the solutions used in large companies it should be expected. The reasons for this set of features lie both within the general characteristics of SMEs, and within the specific principles of project management and the properties of their life cycle (Westland, 2007).

Reasons and basic goals of project are identified at the stage when the project is being initiated. Employing project management may be very beneficial to organizations. This includes structural and operational benefits, as well as business enhancement and improved business benefits (Soriano, 2011). Some of these advantages, such as quality improvement, increased efficiency, or faster implementation of activities may be linked to the protection and enhancement of the existing organizational resources. Other advantages, such as increased revenues, are largely connected with the search for and acquisition of new resources. It seems that in the natural absence of resources in SMEs, particularly in the area of tangible and financial assets (Welsh \& White, 1981; Winston \& Dologite, 1999), these companies tend to focus on the latter category of benefits. This leads to the formulation of the following hypothesis:

H1: Project management in SMEs is primarily focused on the search for and acquisition of new material and financial resources.

At the stage of project planning and arrangement, a project team is formed, which may also be influenced by SMEs' resource shortages. It seems the selection of project team members in SMEs depends more on the project budget, while in LEs there is more emphasis on the qualifications, skills, and knowledge of project participants. This leads to the formulation of another hypothesis:

H2: The selection of project team members in SMEs depends largely on the budget allocated to the project.

Murphy and Ledwith (2007) observed that in SMEs there was a need to precisely clarify the project goals and ensure the support of the owner-manager in project implementation, particularly their involvement in controlling the qualitative criteria of the undertaking. This stems from the dominant role of a private ownermanager in small-business organization (Quinn, 1997; Marcati, Guido \& Pelusob, 2008; Tomczyk, Lee \& Winslow, 2013), oriented towards preserving high operational autonomy (Jones, 2003). This qualitative feature is particularly important at the project implementation stage, as the owner - intending to preserve the autonomy of action - struggles for full control over project performance, which leads to the formulation of the following hypothesis:

H3: In project management in SMEs, the key supervisory and leadership role is performed by the company owner who strives for full control over project implementation.

The pursuit of high autonomy in the process of project implementation in SMEs may also 
result in limiting the scope in which interorganizational cooperation is used. The studies by Bakker, Knoben, de Vries, and Oerlemans (2011) show that small and medium-sized businesses use cooperation mainly in the performance of simple and repetitive tasks (less frequently unique ones) and base it primarily on partnerships, which reduces possible conflicts between partners (Gardiner \& Simmons, 1998). This brings us to yet another hypothesis, reading as follows:

H4: In the process of project implementation, small and medium-sized enterprises only use inter-organizational cooperation to a limited extent, focusing rather on independent action.

Another significant feature influencing the characteristics of project management in SMEs is the relatively low level of formalization, and the high flexibility of action. O'Sheedy, Xu, and Sankaran (2010) emphasize the considerable usefulness of project management in SMEs being executed in a flexible and responsive manner, which is the best solution in a changing and highly uncertain environment. This is manifested by adopting less bureaucratic methods of project management in SMEs than in LEs (Turner, Ledwith \& Kelly, 2010), which might significantly affect the phase of project completion and evaluation. The lack of technical knowledge and experience of SMEs may also be an issue (Stair, Crittenden \& Crittenden, 1989; Bacon, Ackers, Storey \& Coates, 1996), particularly with respect to their use of IT support. This leads to the formulation of the fifth hypothesis:

H5: Project management in SMEs is characterized by relatively low formalization, which leads to a limited use of organizational and IT instruments, advanced and formalized forms of group communication, as well as a formally limited stage of project completion and evaluation.

The study hypotheses formulated above indicate a specific set of qualitative characteristics in the process of project management in SMEs. The hypotheses have been verified by empirical studies, as reported in the latter portion of the paper.

\section{Methodology}

The aims of this paper were pursued and the research hypotheses were verified in the course of studies conducted on a sample of $N=897$ entities operating and implementing projects in the European Union. The research employed the survey method, which is regarded as the main data collection method in studies on entrepreneurship and small business (Newby, Watson \& Woodliff, 2003; Bartholomew \& Smith, 2006). The sample was selected at random based on a sampling frame that included enterprises that had implemented projects significant to their business in the past three years. For the purpose of data analysis, the surveyed entities were grouped into two categories: SMEs (including micro, small, and medium-sized enterprises), and large companies (LEs).

The criterion for SME identification was the uniform formal definition given in the European Commission recommendation (2003) and in the European Commission regulation (2004). Using this approach, $n=563$ SMEs were identified, including $n=154$ micro, $n=231$ small, and $n=178$ medium-sized businesses. In the analysis of study results, the term "small and medium-sized enterprises (SMEs)" was used with reference to all of these companies. The large business category was represented by $n=334$ entities.

The surveyed businesses mostly operated in the service sector $(64.1 \%)$, less frequently they were involved in production $(38.9 \%)$ or trade $(34.8 \%)$. The results do not add up to 100 percent, as $30.2 \%$ of entities were active in more than one sector. The overwhelming majority of the surveyed micro and small companies operated locally and regionally, which is characteristic of small-scale entities (Giaoutzi, Nijkamp \& Storey, 1988). On the other hand, medium-sized and large companies operated more frequently on a national, international, or global scale.

All of the surveyed entities implemented specific projects in the course of their operation. The questionnaire asked the respondents to provide answers with reference to one specific project that had been of significant (strategic) importance to the operation of the entity, and the management of which had been representative of the general principles of project management in the given organization. 
The respondents were representatives of the surveyed companies involved in project implementation. They were members $(91 \%)$ or supervisors $(9 \%)$ of project teams. They had all participated directly or indirectly in all stages of the life cycles of the projects (Westland, 2007).

The first items under analysis were select quantitative parameters of the surveyed projects: their budgets and term of implementation. The results demonstrate that the project budget size is significantly related to the company size, $X^{2}{ }_{\text {yates }}(6, N=897)=97.16$, $p<0.001$. The strength of this relationship, as measured with Cramer's $V=0.23$, indicates a moderate correlation between the properties under study. Moreover, the empirical data show that larger enterprises implement larger projects (in terms of budget size).

The length of time given to project implementation is also significantly related to the company size, $X^{2}(6, N=897)=58.81$, $p<0.001$. The strength of this relationship, as measured with Cramer's $V=0.18$, indicates a moderately weak correlation between the variables. In this case, the empirical data also demonstrate that larger companies tend to implement longer projects (in terms of the duration of implementation).

In order to identify the qualitative areas of project management characteristics in SMEs, the statistical test for the difference between two population proportions was employed (Goodwin \& Kemp, 1979; Anderson, Williams \& Sweeney, 2011; Aczel, 2012). So as to display the statistically significant differences in responses from the representatives of SMEs and LEs, the hypothesis $\mathrm{H}_{0}: p_{S M E}=p_{L E}$ versus its alternative $\mathrm{H}_{1}: p_{S M E} \neq p_{L E}$ was verified with reference to each question. The $\mathrm{H}_{0}$ hypothesis was verified using the statistical $z$ score expressed with a suitable formula, which assuming the truthfulness of $\mathrm{H}_{0}$, has an asymptotically normal distribution. The process of research hypothesis verification (Lehmann \& Romano, 2005) adopted significance level $\alpha=0.05$ and $\alpha=0.01$, and a two-tailed critical region. The results were analyzed with reference to particular phases and the relevant selected qualitative aspects of project management connected with the formulated research hypotheses.

\section{Results}

The analysis of the project initiation phase focused on the assessment of differences occurring at the level of the reasons and objectives for project implementation. The responses of the representatives of small, medium-sized, and large enterprises are presented in Table 1.

In the analysis of the project planning and arrangement phase, attention was given to the criteria for project team member selection and

\begin{tabular}{|c|c|c|c|c|}
\hline \multirow[t]{2}{*}{ Tab. 1: } & \multicolumn{4}{|c|}{$\begin{array}{l}\text { Differences in project management in SMEs and LEs at the project initiation } \\
\text { stage }\end{array}$} \\
\hline & Key project causes and goals & $\begin{array}{l}\text { Percentage } \\
\text { of SMEs }\end{array}$ & $\begin{array}{l}\text { Percentage } \\
\text { of LEs }\end{array}$ & z \\
\hline \multicolumn{2}{|c|}{ Client's market order } & $32.1 \%$ & $16.5 \%$ & $5.16^{* *}$ \\
\hline \multicolumn{2}{|c|}{ Expansion of business and market offer } & $17.1 \%$ & $12.3 \%$ & 1.92 \\
\hline \multicolumn{2}{|c|}{ Quality improvement } & $49.0 \%$ & $63.8 \%$ & $-4.29^{* \star}$ \\
\hline \multicolumn{2}{|c|}{ Increasing efficiency } & $49.20 \%$ & $57.49 \%$ & $-2.40^{*}$ \\
\hline \multicolumn{2}{|c|}{$\begin{array}{l}\text { Shortening the time of processes or other operations } \\
\text { in the company }\end{array}$} & $30.0 \%$ & $40.7 \%$ & $-3.27^{\star *}$ \\
\hline \multicolumn{2}{|c|}{ Reduction of operational costs } & $23.6 \%$ & $36.5 \%$ & $-4.14^{\star *}$ \\
\hline \multicolumn{2}{|c|}{ Increasing revenues } & $68.6 \%$ & $55.4 \%$ & $3.97^{* *}$ \\
\hline \multicolumn{2}{|c|}{ Customer retention } & $53.8 \%$ & $51.2 \%$ & 0.76 \\
\hline \multicolumn{2}{|c|}{ Increasing competitiveness } & $70.2 \%$ & $68.3 \%$ & 0.60 \\
\hline \multicolumn{2}{|c|}{ Adjustment to external requirements } & $3.0 \%$ & $1.5 \%$ & 1.43 \\
\hline
\end{tabular}

${ }^{*} p<0.05 ;{ }^{* *} p<0.01$. Test for the difference between two population proportions (2-tailed). 


\begin{tabular}{|c|c|c|c|c|}
\hline \multirow[t]{2}{*}{ Tab. 2: } & \multicolumn{4}{|c|}{$\begin{array}{l}\text { Differences in project management in SMEs and LEs at the project planning } \\
\text { and arrangement stage }\end{array}$} \\
\hline & $\begin{array}{l}\text { Project team member } \\
\text { selection criteria }\end{array}$ & $\begin{array}{l}\text { Percentage } \\
\text { of SMEs }\end{array}$ & $\begin{array}{l}\text { Percentage } \\
\text { of LEs }\end{array}$ & $\mathbf{z}$ \\
\hline \multicolumn{2}{|c|}{ Project budget size } & $34.1 \%$ & $28.1 \%$ & 1.85 \\
\hline \multicolumn{2}{|c|}{ Skills and knowledge } & $89.2 \%$ & $89.8 \%$ & -0.31 \\
\hline \multicolumn{2}{|c|}{ Limited term of project implementation } & $17.8 \%$ & $19.2 \%$ & -0.52 \\
\hline \multicolumn{2}{|c|}{ Other criteria } & $3.2 \%$ & $2.7 \%$ & 0.43 \\
\hline \multicolumn{2}{|r|}{ Use of computer tools and software } & $\begin{array}{l}\text { Percentage } \\
\text { of SMEs }\end{array}$ & $\begin{array}{l}\text { Percentage } \\
\text { of LEs }\end{array}$ & $\mathbf{z}$ \\
\hline \multicolumn{2}{|c|}{ No use of tools and software } & $39.1 \%$ & $13.5 \%$ & $8.13^{* *}$ \\
\hline \multicolumn{2}{|c|}{ Project schedule } & $48.8 \%$ & $67.7 \%$ & $-5.49^{* *}$ \\
\hline \multicolumn{2}{|c|}{ Project implementation chart } & $18.1 \%$ & $24.6 \%$ & $-2.31^{*}$ \\
\hline \multicolumn{2}{|c|}{ Network diagrams } & $3.7 \%$ & $8.4 \%$ & $-2.96^{\star *}$ \\
\hline \multicolumn{2}{|c|}{ Other tools } & $1.1 \%$ & $2.4 \%$ & -1.55 \\
\hline \multicolumn{2}{|c|}{ Computer software } & $30.0 \%$ & $47.0 \%$ & $-5.11^{* *}$ \\
\hline
\end{tabular}

${ }^{*} p<0.05 ;{ }^{* *} p<0.01$. Test for the difference between two population proportions (2-tailed).

to the use of organizational and IT instruments in project planning. The responses of the representatives of small, medium-sized, and large enterprises are presented in Table 2.

As concerns the projectimplementation phase, observations focused on the solutions used in project supervision, the use of inter-organizational cooperation, advanced technologies, and the forms of group communication. The responses of the representatives of small, medium-sized, and large enterprises are presented in Table 3.

In the analysis of the project completion and evaluation phase, attention was paid to the entity performing the project assessment, the degree of attainment of the intended goals, and the scope of retaining the knowledge generated in the course of the project. The responses of the representatives of small, medium-sized, and large enterprises are presented in Table 4.

\section{Discussion}

The study results presented suggest the occurrence of significant areas of characteristics in all phases of the life cycle of SME projects. With reference to the initiation stage, the analysis concerned the major reasons and goals of the projects. The results indicate that SMEs more often implement projects in order to achieve effects related to direct market actions. It may be stated that in this case, project management is rather more externally oriented (marketoriented). Large firms, on the other hand, are more focused on the pursuit of developmental goals: quality improvement, both with respect to products and services, and internal procedures - in order to increase efficiency or reduce the time it takes to implement processes or other business activities.

Considerable differences at this stage also appear in the companies' approach to the issue of effectiveness. SMEs are characterized by a higher orientation to efficiency, dominated by the intention to increase revenues (which fits well with market-oriented project management). On the other hand, large firms prefer the economical option connected with optimization and reduction of operational costs. These differences may also provide grounds for conclusions related to the creation of the competitive advantage within the framework of the resource-based view (Barney \& Clark, 2007; Jugdev, Mathur \& Fung, 2007) by comparing groups of entities. If SMEs (due to resource shortages) tend to focus rather more on obtaining new sources of financing, the large companies aim to protect their existing assets and improve them by undertaking economical and developmental initiatives. Therefore, the results support a positive verification of the $\mathrm{H} 1$ hypothesis in terms of financial 


\begin{tabular}{|c|c|c|c|}
\hline $\begin{array}{l}\text { Tab. 3: } \begin{array}{l}\text { Differences in project management it } \\
\text { implementation stage }\end{array}\end{array}$ & MEs and $L$ & it the proj & \\
\hline $\begin{array}{l}\text { Supervision of } \\
\text { project implementation }\end{array}$ & $\begin{array}{l}\text { Percentage } \\
\text { of SMEs }\end{array}$ & $\begin{array}{l}\text { Percentage } \\
\text { of LEs }\end{array}$ & $\mathbf{z}$ \\
\hline Company owner & $57.0 \%$ & $26.7 \%$ & $8.83^{* *}$ \\
\hline Company employee or manager & $16.7 \%$ & $38.0 \%$ & $-7.17^{* *}$ \\
\hline Contractor's employee & $6.7 \%$ & $7.8 \%$ & -0.58 \\
\hline External consultant & $7.8 \%$ & $4.5 \%$ & 1.94 \\
\hline Team supervision & $11.7 \%$ & $22.5 \%$ & $-4.27^{* *}$ \\
\hline Other solutions & $0.0 \%$ & $0.6 \%$ & -1.84 \\
\hline $\begin{array}{c}\text { Inter-organizational cooperation in project } \\
\text { implementation }\end{array}$ & $\begin{array}{l}\text { Percentage } \\
\text { of SMEs }\end{array}$ & $\begin{array}{l}\text { Percentage } \\
\text { of LEs }\end{array}$ & $\mathbf{z}$ \\
\hline Inter-organizational cooperation & $46.0 \%$ & $56.9 \%$ & $-3.15^{\star *}$ \\
\hline $\begin{array}{l}\text { Use of group communication forms in project } \\
\text { implementation }\end{array}$ & $\begin{array}{l}\text { Percentage } \\
\text { of SMEs }\end{array}$ & $\begin{array}{l}\text { Percentage } \\
\text { of LEs }\end{array}$ & $\mathbf{z}$ \\
\hline Meetings & $90.4 \%$ & $88.6 \%$ & 0.85 \\
\hline Conference calls & $18.3 \%$ & $27.5 \%$ & $-3.25^{* *}$ \\
\hline Videoconferences & $1.4 \%$ & $6.3 \%$ & $-3.98^{* *}$ \\
\hline Stationary phones & $76.6 \%$ & $88.9 \%$ & $-4.58^{* *}$ \\
\hline Cellular phones & $87.6 \%$ & $82.3 \%$ & $2.16^{*}$ \\
\hline Satellite phones & $4.3 \%$ & $10.8 \%$ & $-3.78^{* *}$ \\
\hline Internet & $75.0 \%$ & $77.8 \%$ & -0.98 \\
\hline Intranet & $31.4 \%$ & $66.5 \%$ & $-10.21^{\star \star}$ \\
\hline Extranet & $4.1 \%$ & $11.1 \%$ & $-4.05^{\star *}$ \\
\hline No use of network connections & $18.1 \%$ & $7.5 \%$ & $4.42^{* *}$ \\
\hline $\begin{array}{l}\text { Use of advanced technologies } \\
\text { in project implementation }\end{array}$ & $\begin{array}{l}\text { Percentage } \\
\text { of SMEs }\end{array}$ & $\begin{array}{l}\text { Percentage } \\
\text { of LEs }\end{array}$ & $\mathbf{z}$ \\
\hline High-tech equipment & $46.7 \%$ & $39.8 \%$ & $2.01^{*}$ \\
\hline High-tech products & $21.7 \%$ & $21.0 \%$ & 0.25 \\
\hline High-tech services & $20.6 \%$ & $21.0 \%$ & -0.13 \\
\hline Computer software & $41.7 \%$ & $54.5 \%$ & $-3.70^{* *}$ \\
\hline
\end{tabular}

${ }^{*} p<0.05 ;{ }^{* *} p<0.01$. Test for the difference between two population proportions (2-tailed).

assets that constitute the key resources in SME growth (Serrasqueiro \& Nunes, 2011). Small and medium-sized companies prefer internal sources of financing (García-Teruel \& Martínez-Solano, 2007), which means that project management helps in supplementing them.

In the analysis of the project planning and arrangement stage, one needs to consider that in the area related to the selection of project team members there are no significant differences between SMEs and LEs. In both groups, the leading criterion is the one concerning the skills and knowledge of candidates. This does not provide positive verification for the $\mathrm{H} 2$ hypothesis.

However, significant differences at this stage are found with respect to the use of organizational and IT instruments in project planning. The study results show that SMEs are less inclined to use organizational tools, and tend to make less use of computer software supporting project planning.

One might thus conclude that the project planning and arrangement stage in SMEs 
Tab. 4: Differences in project management in SMEs and LEs at the project completion and evaluation stage

\begin{tabular}{|c|c|c|c|}
\hline Entity performing project evaluation & $\begin{array}{l}\text { Percentage } \\
\text { of SMEs }\end{array}$ & $\begin{array}{l}\text { Percentage } \\
\text { of LEs }\end{array}$ & $\mathbf{z}$ \\
\hline Client & $22.7 \%$ & $17.4 \%$ & 1.92 \\
\hline Expert uninvolved in the project & $9.8 \%$ & $11.4 \%$ & -0.76 \\
\hline Contractor's representative & $7.6 \%$ & $4.8 \%$ & 1.66 \\
\hline Project supervisor & $40.5 \%$ & $51.2 \%$ & $-3.12^{* *}$ \\
\hline Company employee uninvolved in the project & $13.3 \%$ & $16.8 \%$ & -1.41 \\
\hline Member of strict company management & $7.3 \%$ & $5.4 \%$ & 1.11 \\
\hline External regulatory body & $4.4 \%$ & $3.3 \%$ & 0.85 \\
\hline No project evaluation was performed & $29.0 \%$ & $21.3 \%$ & $2.54^{*}$ \\
\hline $\begin{array}{l}\text { Degree of attainment of intended } \\
\text { project goals }\end{array}$ & $\begin{array}{l}\text { Percentage } \\
\text { of SMEs }\end{array}$ & $\begin{array}{l}\text { Percentage } \\
\text { of LEs }\end{array}$ & $\mathbf{z}$ \\
\hline Full & $87.4 \%$ & $79.4 \%$ & $3.16^{\star *}$ \\
\hline Partial & $12.2 \%$ & $19.9 \%$ & $-3.10^{* *}$ \\
\hline None & $0.4 \%$ & $0.6 \%$ & -0.54 \\
\hline $\begin{array}{l}\text { Retention of knowledge generated in } \\
\text { project implementation }\end{array}$ & $\begin{array}{l}\text { Percentage } \\
\text { of SMEs }\end{array}$ & $\begin{array}{l}\text { Percentage } \\
\text { of LEs }\end{array}$ & $\mathbf{z}$ \\
\hline Knowledge was retained & $68.2 \%$ & $78.7 \%$ & $-3.40^{* *}$ \\
\hline
\end{tabular}

${ }^{*} p<0.05 ;{ }^{* *} p<0.01$. Test for the difference between two population proportions (2-tailed).

is characterized by lower formalization and a limited scope of use of organizational and IT instruments as compared to large enterprises. The results obtained confirm the $\mathrm{H} 5$ hypothesis with regard to lower formalization and limited use of organizational and IT instruments. The reason for this situation is the absence of specific organizational tools and computer software that might be used by SMEs in the project management process. Another problem may be the limited knowledge and skills of entrepreneurs in implementing initiatives and IT systems (Santos, Montoni, Vasconcellos, Figueiredo, Cabral, Cerdeiral, Katsurayama, Lupo, Zanetti \& Rocha, 2007).

The analysis of the direct project implementation stage revealed significant differences in project management between SMEs and LEs - occurring in each of the areas under study. The first one concerns the supervision of project implementation. In SMEs, this is usually performed directly by the company owner. The supervision is mostly of a statistical nature, and the supervising entity remains unchanged throughout the project implementation period. This supports the $\mathrm{H} 3$ hypothesis.

In large firms, the management is teambased, collective, or it is performed within matrix structures. Supervising collectives usually include members of the leading entity (LE) and its partners and subcontractors. Therefore, managing is often dynamic, and supervisors change from stage to stage.

The results illustrate that SMEs indeed tend to use inter-organizational cooperation in project implementation to a lesser extent than LEs. This limited tendency for interorganizational cooperation primarily stems from the smaller scope of their projects (in terms of budget size and term of implementation). Larger enterprises more frequently implement complex projects, requiring the involvement of many subcontractors, whereas SMEs usually implement simpler projects, only engaging their internal potential and resources. The results support the $\mathrm{H} 4$ hypothesis.

The next area under study concerned the use of various forms of group communication in the course of project implementation. The 
results show that SMEs use high-tech forms of telecommunication much less than LEs do. The biggest differences occur in the use of videoconference, satellite telephony, and conference calls. At a low level of significance, SMEs use cellular phones more often than LEs. This is largely due to the limited communication needs in SMEs, connected with their smaller sizes, employment and limited spatial dispersion. However, it also confirms the necessity to develop appropriate solutions in the area of internal communication within small and medium-sized companies (Holá, 2012).

Significant differences also concern the use of computer networks in the course of project implementation. Because of their characteristics, SMEs make much less use of the intranet and extranet. It should also be emphasized that many more SMEs do not use IT networks in project implementation at all. Thus, the results obtained in this section of the study support the $\mathrm{H} 5$ hypothesis with reference to the limited use of advanced and formalized forms of group and network communication.

Another area of research concerned the use of advanced technologies in project implementation. The results show that at a low level of significance, SMEs tend to make slightly more use of high-tech equipment - machinery and devices. These findings may raise some doubts, as in fact large enterprises use computer software substantially more frequently in project implementation, and as it was indicated above, they also use advanced forms of group communication to a greater extent.

The answers of SMEs gave concerning the scope of their use of high-tech equipment may be attributed to two reasons. Perhaps, these entities make greater use of small but highly specialized devices (measuring or production equipment) than LEs. On the other hand, due to their inherent resource shortages, SMEs tend to view various technologies as advanced. The purchase of the same machine by a large company may be seen as a lowtech investment. There is no doubt, however, that the implementation of projects by SMEs and LEs substantially affects the acquisition of new technological solutions and necessary material resources. Therefore, it supports the $\mathrm{H} 1$ hypothesis in terms of acquisition of new material assets.

The last phase was project completion and evaluation. In this case, SMEs performed a full evaluation of the project significantly less frequently, whereas this was usually done by the project supervisor in LEs. This is due to both the lower level of formalization of the project management process in SMEs, and the fact that static project supervision is usually performed by the business owner who supervises the project on a real-time basis.

Despite this weakness, the results show that SMEs fully achieve the intended goals of their projects much more frequently. This happens for two reasons: first, SMEs implement smaller projects, which make the attainment of their goals easier; second, LEs tend to implement more complex projects involving many subcontractors and partners (greater degree of inter-organizational cooperation). In this case, the final project outcome is composed of the implementation of many fragmentary tasks, some of which may be outside the immediate control of the large entity. Mistakes or gaps in their implementation negatively affect the final evaluation of project goal attainment. Surely, the study results may also be attributed to the lower level of formalization of the project completion phase in SMEs, where the assessment is more superficial, which allows them to record higher efficiency ratios.

The lower formalization of the project completion stage also translates into lower retention of the knowledge generated in project implementation in SMEs. It may additionally stem from limited capabilities (e.g., limited use of IT) or the needs of smaller businesses. The results obtained in this section positively verify the $\mathrm{H} 5$ hypothesis with regard to the formal limitations of the project completion and evaluation process.

Based on the research findings and their discussion, Table 5 presents the key areas of characteristics in the process of project management in SMEs as compared to the solutions employed by LEs. In addition, the results were referred to the verification of individual study hypotheses.

Therefore, it may be stated that the characteristics of project management in SMEs are made manifest by an external orientation focused on increasing efficiency and the search for new resources, pursued with limited use of formalized management methods and tools. The management process is dominated by static leadership of the company owner, the limited scope of inter-organizational cooperation, and 
Tab. 5:

Key areas of characteristics in project management in small and medium-sized enterprises

\begin{tabular}{l|c|c|c}
\multicolumn{1}{c|}{ Area } & SMEs & $\begin{array}{c}\text { Large } \\
\text { enterprises }\end{array}$ & $\begin{array}{c}\text { Hypothesis } \\
\text { verification }\end{array}$ \\
\hline \multicolumn{3}{c}{ Project initiation phase } \\
\hline Dominant project orientation & external (market) & internal & $\mathrm{H} 1$ \\
\hline Dominant project variant & efficient & economical & \\
\hline Approach to resources & $\begin{array}{c}\text { search for new } \\
\text { resources }\end{array}$ & $\begin{array}{c}\text { protection and } \\
\text { enhancement of } \\
\text { resources held }\end{array}$ & $\mathrm{H} 1$ \\
\hline
\end{tabular}

\begin{tabular}{|c|c|c|c|}
\hline \multicolumn{4}{|c|}{ Project planning and arrangement phase } \\
\hline Formalization & low & high & $\mathrm{H} 5$ \\
\hline Use of organizational instruments & limited & high & $\mathrm{H} 5$ \\
\hline Use of IT support & limited & high & H5 \\
\hline \multicolumn{4}{|c|}{ Project implementation phase } \\
\hline Dominant type of supervision & static & dynamic & $\mathrm{H} 3$ \\
\hline Dominant supervisory unit & company owner & $\begin{array}{l}\text { employee or hired } \\
\text { manager }\end{array}$ & $\mathrm{H} 3$ \\
\hline Scope of inter-organizational cooperation & limited & high & $\mathrm{H} 4$ \\
\hline Forms of group communication & $\begin{array}{c}\text { less } \\
\text { technologically- } \\
\text { advanced }\end{array}$ & $\begin{array}{c}\text { more } \\
\text { technologically- } \\
\text { advanced }\end{array}$ & H5 \\
\hline Use of IT networks & low & high & $\mathrm{H} 5$ \\
\hline $\begin{array}{l}\text { Influence on investments in new } \\
\text { technologies }\end{array}$ & significant & limited & $\mathrm{H} 1$ \\
\hline \multicolumn{4}{|c|}{ Project completion and evaluation phase } \\
\hline Scope of project evaluation & limited & extensive & $\mathrm{H} 5$ \\
\hline $\begin{array}{l}\text { Degree of attainment of intended project } \\
\text { goals }\end{array}$ & extensive & limited & $\mathrm{H} 5$ \\
\hline Retention of knowledge & limited & extensive & $\mathrm{H} 5$ \\
\hline
\end{tabular}

the use of less technologically advanced forms of group communication. Nevertheless, despite the limited scope and limited formalization of assessment, project implementation in SMEs produces a higher degree of attainment of intended goals oriented towards obtaining new financial assets and the development of new technological equipment.

\section{Limitations of and Future Directions for Research}

The research results presented in this paper and the conclusions drawn on their basis are not free from methodological limitations and doubts. These limitations primarily stem from the induction-based research approach (Popper, 2002) and the use of surveys as the source of empirical data (Coughlan, Cronin \& Ryan, 2009). First, the generalizability of our results may be limited, as the observations only covered a relatively small group of entities as compared to the entire population of businesses operating in the EU.

Secondly, the analysis only concerned the selected qualitative aspects of the project management process, characteristic of particular stages in the project life cycle. This approach only allows limited conclusions to be drawn about the qualitative features of project 
management in SMEs. Finally, the studies were conducted with regard to only one, selected project in each entity. The respondents were asked to choose projects that would be representative from the point of view of the management methods used, but the solutions employed in the implementation of other projects may be different and consequently, may reduce the cognitive value of the research. Despite these limitations, our studies, incorporating findings from review of the relevant literature, enable the identification of specific conclusions regarding the selected aspects of the qualitative properties of project management in small and medium-sized enterprises.

The research should definitely be continued. Without a doubt, in-depth qualitative research in the form of case studies would be of value, allowing the appreciation of the managerial characteristics in the process of project management in SMEs in specific contexts. Attention should also be given to the search for areas of diversification and denaturation in project management in SMEs, enabling a more comprehensive description of this subject.

\section{Conclusions}

The search for general and functional characteristics is an important theoretical and empirical trend in studies on the management of small and medium-sized businesses. It plays a significant part not only in the process of SME definition, but also enables a deeper understanding of the nature and motivation of small-business management. Research in this area is also an important source of information for solutions supporting companies in this sector and for entities treating SMEs as a category of target clients, partners, competitors, or cooperators.

The present paper focused on searching for qualitative functional characteristics of SMEs in the area of project management. A review of the literature demonstrated that the characteristics do stem from the general properties of small business, but they also must take into account the peculiar challenges of the project management process. Thus, the considerations were referred to consecutive phases in project life cycle, and comparative studies were conducted on a sample of SMEs and LEs.

The results produced enabled the positive verification of four research hypotheses formulated in the theoretical section. On this basis, it may be stated that project management in SMEs is primarily focused on the search and acquisition of new material and financial resources. The key supervisory and leadership role is performed by the company owner who strives for full control over project implementation. The pursuit of high autonomy limits the extent of inter-organizational cooperation in the project management process. The results also show that project management in SMEs is characterized by relatively low formalization, which leads to a limited use of organizational and IT instruments, advanced and formalized forms of group communication, as well as a formally limited stage of project completion and evaluation.

On the other hand, the studies failed to confirm the $\mathrm{H} 2$ hypothesis, stating that the selection of project team members in SMEs depends largely on the budget allocated to the project. In this case, the results did not point to any substantial differences between the SMEs and LEs under study. In both groups, the skills and knowledge of candidates were the key selection criterion.

In summary of the analysis, we conclude that strong points of project management in SMEs include external orientation based on the efficiency-geared approach, focused on the search for new resources, which enables company growth and development, often based on new technological solutions. Other advantages that should be mentioned are higher effectiveness (as measured by the degree of attainment of intended goals) and lower formalization, which translates into higher operational flexibility.

On the other hand, the weaknesses of project management in SMEs mostly concern the limited use of advanced IT and organizational support, as well as the limited use of benefits of inter-organizational cooperation allowing an investment-free expansion of business scope. Other negatives include static supervision concentrated in the owner, the limited scope of project evaluation, and limited retention of knowledge generated in project implementation.

Although the research is characterized by some limitations in methodology, it has lead to new cognitive findings concerning the properties of small and medium-sized enterprises in the area of project management. Further studies are planned. There is hope that these studies will produce a number of new and more specific cognitive and applicable conclusions. 


\section{References}

Aczel, A.D. (2012). Complete business statistics. Morristown, $\mathrm{NJ}$ : Wohl Publishing.

Allocca, M.A., \& Kessler, E.H. (2006). Innovation speed in small and mediumsized enterprises. Creativity and Innovation Management, 15(3), 279-295. doi:10.1111/ j.1467-8691.2006.00389.x.

Alpkan, L., Yilmaz, C., \& Kaya, N. (2007). Market orientation and planning flexibility in SMEs. Performance implications and an empirical investigation. International Small Business Journal, 25(2), 152-172. doi:10.1177/0266242607074518.

D'Amboise, G., \& Muldowney, M. (1988). Management theory for small business: attempts and requirements. The Academy of Management Review, 13(2), 226-240. doi:10.5465/AMR.1988.4306873.

Anderson, D., Williams, T., \& Sweeney, D. (2011). Fundamentals of business statistics. Mason, $\mathrm{OH}$ : Cengage Learning.

Ayyagari, M., Beck, T., \& Demirguc-Kunt, A. (2007). Small and medium enterprises across the globe. Small Business Economics, 29(4), 415-434. doi:10.1007/s11187-006-9002-5.

Bacon, N. et al. (1996). It's a small world: managing human resources in small businesses. The International Journal of Human Resource Management, 7(1), 82-100. doi:10.1080/09585199600000119.

Bakker, R.M., Knoben, J., de Vries, N., \& Oerlemans, L.A.G. (2011). The nature and prevalence of inter-organizational project ventures: evidence from a large scale field study in the Netherlands 2006-2009. International Journal of Project Management, 29(6), 781794. doi: 10.1016/j.ijproman.2010.04.006.

Bannier, C.E., \& Zahn, S. (2012). Are SMEs large firms in miniature? Evidence from the growth of German SMEs. International Journal of Entrepreneurship and Small Business, 17(2), 220-248. doi:10.1504/IJESB.2012.048848.

Barney, J.B., \& Clark, D.N. (2007). Resource-based theory: creating and sustaining competitive advantage. Oxford: Oxford University Press.

Barrett, R., \& Mayson, S. (2007). Human resource management in growing small firms. Journal of Small Business and Enterprise Development, 14(2), 307-319. doi:10.1108/14626000710746727.

Bartholomew, S., \& Smith, A.D. (2006). Improving survey response rates from chief executive officers in small firms: the importance of social networks. Entrepreneurship Theory and Practice, 30(1), 83-96. doi:10.1111/j.15406520.2006.00111.x.

Blili, S., \& Raymond, L. (1993) Information technology: threats and opportunities for small and medium-sized enterprises. International Journal of Information Management, 13(6), 439-448. doi:10.1016/0268-4012(93)90060-H.

Carrier, C. (1994). Intrapreneurship in large firms and SMEs: a comparative study. International Small Business Journal, 12(3), 5461. doi:10.1177/0266242694123005.

Commission Recommendation. (2003). 2003/361/EC concerning the definition of small and medium-sized enterprises. Official Journal of the European Union, 46(L 124), 36-41. Retrieved from http:// eur-lex.europa.eu/LexUriServ/LexUriServ. do?uri=OJ:L:2003:124:0036:0041:en:PDF.

Commission Regulation. (2004). No 364 amending regulation (EC) No 70/2001 as regards the extension of its scope to include aid for research and development. Official Journal of the European Union, 47(L 63), 22-39.

Coppa, M., \& Sriramesh, K. (2013). Corporate social responsibility among SMEs in Italy. Public Relations Review, 39(1), 30-39. doi:10.1016/j.pubrev.2012.09.009.

Coughlan, M., Cronin, P., \& Ryan, F. (2009). Survey research: process and limitations. International Journal of Therapy \& Rehabilitation, 16(1), 9-15. doi:10.12968/ ijtr.2009.16.1.37935.

Curran, J., \& Blackburn, R.A. (2001). Researching the small enterprise. London: Sage.

Curran, J., \& Burrows, R. (1993). Shifting the focus: problems and approaches in studying the small enterprise in the services sector. In R. Atkin, E. Chell, \& C. Mason (Eds.), New directions in small business research (pp. 177191). Aldershot: Ashgate.

Curran, J. (2006). Comment: 'Specificity' and 'Denaturing' the Small Business. International Small Business Journal, 24(2), 205-210. doi:10.1177/0266242606062433.

Dandridge, T.C. (1979). Children are not little grown-ups: small business needs its own organizational theory. Journal of Small Business Management, 17(2), 53-57.

Fernández-Ribas, A. (2010). International patent strategies of small and large firms: an empirical study of nanotechnology. Review of 
Policy Research, 27(4), 457-473. doi:10.1111/ j.1541-1338.2010.00451.x.

Fong, E., Chen, W., \& Luk, C. (2012). A study of locational distribution of small and large ethnic businesses in a multiethnic city: Chinese in Toronto, Canada. Journal of Small Business Management, 50(4), 678-698. doi:10.1111/j.1540-627X.2012.00371.x.

García-Teruel, P.J., \& Martínez-Solano, P. (2007). Short-term debt in Spanish SMEs. International Small Business Journal, 25(6), 579-602. doi:10.1177/0266242607082523.

Gardiner, P.D., \& Simmons, J.E.L. (1998). Conflict in small- and medium-sized projects: case of partnering to the rescue. Journal of Management in Engineering, 14(1), pp. 35-39. doi:10.1061/(ASCE)0742-597X.

Garel, G.A. (2013). History of project management models: from pre-models to the standard models. International Journal of Project Management, 31(5), 663-669. doi:10.1016/j.jproman.2012.12.011.

Gartner, W.B., Bird, B.J., \& Starr, J.A. (1992). Acting as If: differentiating entrepreneurial from organizational behavior. Entrepreneurship Theory and Practice, 16(1), 13-31.

Geroski, P.A. (1999). The growth of firms in theory and in practice (Discussion Paper Series 2092). London: Centre for Economic Policy.

Giaoutzi, M., Nijkamp, P., \& Storey, D.J. (1988). Small is beautiful - the regional importance of small-scale activities. In $\mathrm{M}$. Giaoutzi, P. Nijkamp, \& D.J. Storey (Eds.), Small and medium size enterprises and regional development (pp. 1-19). London: Routledge.

Goodwin, E.M., \& Kemp, J.F. (1979). Tests on differences between proportions. In E.M. Goodwin, \& J.F. Kemp (Eds.), Marine statistics, theory and practice (pp. 187-188). London: Stanford Maritime.

Haltiwanger, J., Jarmin, R., \& Javier, M. (2013). Who creates jobs? Small versus large versus young. The Review of Economics and Statistics, 95(2), 347-361. doi:10.1162/ REST_a_00288.

Holá, J. (2012). Internal Communication in the small and medium sized enterprises. E\&M Ekonomie a Management, 15(3), 32-45.

Honig, B., \& Samuelsson, M. (2012). Planning and the entrepreneur: a longitudinal examination of nascent entrepreneurs in Sweden. Journal of Small Business Management, 50(3), 365-388. doi:10.1111/ j.1540-627X.2012.00357.x.
Jones, O. (2003). The persistence of autocratic management in small firms: TCS and organisational change. International Journal of Entrepreneurial Behaviour and Research, 9(6), 245-267. doi:10.1108/13552550310501365.

Jugdev, K., \& Mathur, G. (2012). Classifying project management resources by complexity and leverage. International Journal of Managing Projects in Business, 5(1), 105-124. doi:10.1108/17538371211192928.

Jugdev, K., Mathur, G., \& Fung, T.S. (2007). Project management assets and their relationship with the project management capability of the firm. International Journal of Project Management, 25(6), 560-568. doi:10.1016/j.jproman.2007.01.009.

Koc, T. (2011). Innovation antecedents: comparative research on large firms and SMEs in Turkey. International Journal of Industrial Engineering, 18(10), 547-558.

Kushnir, K., Mirmulstein, M.L., \& Ramalho, R. (2010). Micro, small, and medium enterprises around the world: how many are there, and what affects the count?. International Finance Corporation and The World Bank. Retrieved September 2, 2013, from http://www.ifc.org/wps/ wcm/connect/9ae1dd80495860d6a482b5195 83 b 6 d 16 / M S ME - CI - An aly s is Note. pdf?MOD=AJPERES.

Kwak, Y.H., \& Anbari, F.T. (2009). Analyzing project management research: perspectives from top management journals. International Journal of Project Management, 27(5), 435446. doi:10.1016/j.jproman.2008.08.004.

Larson, E.W., Gobeli, D.H., \& Gray, C. (1991). Application of project management by small businesses to develop new products and services. Journal of Small Business Management, 29(2), 30-41.

Lehmann, E.L., \& Romano, J.P. (2005). Testing statistical hypotheses. New York: Springer.

Levy, M., \& Powell, P. (2004). Strategies for growth in SMEs: the role of information and information systems. Oxford: Elsevier Butterworth-Heinemann.

Marcati, A., Guido, G., \& Pelusob, A.M. (2008). The role of SME entrepreneurs' innovativeness and personality in the adoption of innovations. Research Policy, 37(9), 15791590. doi:10.1016/j.respol.2008.06.004.

Marchesnay, M. (1982). Is small so beautiful?. Revue d'Économie Industrielle, 19(1), 110-114. 
Mathur, G., Jugdev, K., \& Fung, T.S. (2007). Intangible project management assets as determinants of competitive advantage. Management Research News, 30(7), 460-475. doi:10.1108/01409170710759694.

Mcgrath, R.G., \& Macmillan, I.C. (2009). How to rethink your business during uncertainty. Sloan Management Review, 50(3), 24-30.

Meredith, J.R., \& Mantel, Jr., S.J. (2011). Project management: a managerial approach. New York: John Wiley \& Sons.

Mintzberg, H. (1979). The Structuring of Organizations. A Synthesis of the Research. Englewood Cliffs: Prentice Hall.

Molnár, Z., \& Střelka, J. (2012). Competitive intelligence $v$ malých a středních podnicích. E\&M Ekonomie a Management, 15(3), 156-170.

Murphy, A., \& Ledwith, A. (2007). Project management tools and techniques in hightechnology SMEs. Management Research News, 30(2), 153-166. doi:10.1108/01409170710722973.

Newby, R., Watson, J., \& Woodliff, D. (2003). SME survey methodology: response rates, data quality, and cost effectiveness. Entrepreneurship Theory and Practice, 28(2), 163-172. doi:10.1046/j.1540-6520.2003.00037.x.

Nicolescu, O. (2009). Main features of SMEs organisation system. Review of International Comparative Management, 10(3), 405-413.

O'Sheedy, D.G., XU, J., \& Sankaran, S. (2010). Preliminary results of a study of agile project management techniques for an SME environment. International Journal of Arts and Sciences, 3(7), 278-291.

Patanakul, P., \& Shenhar, A.J. (2012). What project strategy really is: the fundamental building block in strategic project management. Project Management Journal, 43(1), 4-20. doi:10.1002/pmj.20282.

Penrose, E.T. (1959). The theory of the growth of the firm. Oxford: Basic Blackwell.

Popper, K. (2002). The logic of scientific discovery. London, New York: Routledge.

Pugh, D.S., Hickson, D.J., \& Hinings, C.R. (1969). An empirical taxonomy of structure of work organizations. Administrative Science Quarterly, 14(1), 115-126.

Pugh, D.S., Hickson, D.J., Hinings, C.R., \& Tumer, C. (1968). Dimensions of organization structure. Administrative Science Quarterly, 13(1), 65-105.

Quinn, J.J. (1997). Personal ethics and business ethics: the ethical attitudes of owner/managers of small business. Journal of Business Ethics, 16(2), 119-127. doi:10.1023/A:1017901032728.
Rawwas, M.Y.A., \& lyer, K.N.S. (2013). How do small firms possibly survive? A comparison study of marketing skills and logistics infrastructure of small and large wholesalers. International Business Review, 22(4), 687-698. doi:10.1016/j.ibusrev.2012.10.003.

Reboud, S., Mazzarol, T., \& Clark, D. (2011). In Search of the 'SME Ordinaire' - Towards a Taxonomy. In Stockholm: 56th Annual ICSB World Conference. Stockholm: WileyBlackwell. Retrieved August 25, 2013, from http://www.cemi.com.au/sites/all/publications/ Mazzarol\%2C\%20Reboud \% 20and \% 20 Clark\%20ICSB\%202011.pdf.

Santos, G. et al. (2007). Implementing software process improvement initiatives in small and medium-size enterprises in Brazil. In Proceedings of the 6th International Conference on Quality of Information and Communications Technology (pp. 187198). Washington: IEEE Computer Society. doi:10.1109/QUATIC.2007.22.

Serrasqueiro, Z., \& Nunes, P.M. (2011). Is age a determinant of SMEs' financing decisions? Empirical evidence using panel data models. Entrepreneurship Theory and Practice, 36(4), 627-654. doi:10.1111/j.15406520.2010.00433.x.

Söderlund, J. (2011). Pluralism in project management: navigating the crossroads of specialization and fragmentation. International Journal of Management Reviews, 13(2), 153176. doi:10.1111/j.1468-2370.2010.00290.x.

Soriano, J.L. (2011). Maximizing benefits from IT project management: from requirements to value delivery. Boca Raton: CRC Press.

Stair, R.M. Jr., Crittenden, W.F., \& Crittenden, V.L. (1989). The use, operation, and control of the small business computer. Information and Management, 16(3), 125-130.

Stevenson, H.H., \& Jarillo, C. (1990). A paradigm of entrepreneurship: entrepreneurial management. Strategic Management Journal, 11(Special Iss.), 17-27.

Szabo, Z.K., Šoltés, M., \& Herman, E. (2013). Innovative capacity \& performance of transition economies: comparative study at the level of enterprises. E\&M Ekonomie a Management, 16(1), 52-68.

Teece, D.J. (2007). Explicating dynamic capabilities: the nature and microfoundations of (sustainable) enterprise performance. Strategic Management Journal, 28(13), 1319-1350. doi:10.1002/smj.640. 
Teece, D.J., Pisano, G., \& Shuen, A. (1997). Dynamic capabilities and strategic management. Strategic Management Journal, 18(7), 509-533.

Terziovski, M. (2010). Innovation practice and its performance implications in small and medium enterprises (SMEs) in the manufacturing sector: a resource-based view. Strategic Management Journal, 31(8), 892-902. doi:10.1002/smj.841.

Tomczyk, D., Lee, J., \& Winslow, E. (2013). Entrepreneurs' personal values, compensation, and high growth firm performance. Journal of Small Business Management, 51(1), 66-82. doi:10.1177/0266242615584646.

Torrès, O. (2003). A French perspective of research on small business: denaturation and proximity. In 17th Conference of European Council of Small Business (ECSB), RENT XVII. Lodz: ECSB. Retrieved August 27, 2013, from http://www.oliviertorres.net/travaux/pdf/ ECSBLodz.pdf.

Torrès, O., \& Julien, P.A. (2005). Specificity and denaturing of small business. International Small Business Journal, 23(4), 355-377. doi:10.1177/0266242605054049.

Torrès, O. (2004). The proximity law of small business management: between closeness and closure. In 49th Conference of International Council of Small Business (ICSB). Johannesburg: ICSB. Retrieved August 27, 2013, from http://www.oliviertorres.net/travaux/ pdf/otICSBJohan.pdf.

Torrès, O. (2003). Thirty years of research into SMEs: a field of trends and counter-trends. Cahiers de recherché, 6, 1-43.

Tuček, D., Hájková, M., \& Tučková, Z. (2013). Utilization level of Business Process Management in Czech enterprises - objectives and factors. E\&M Ekonomie a Management, 16(2), 81-98.

Turner, R., Ledwith, A., \& Kelly, J. (2010). Project management in small to mediumsized enterprises: matching processes to the nature of the firm. International Journal of Project Management, 28(8), 744-755. doi:10.1108/00251741211227627.

Vahter, P., Love, J.H., \& Roper, S. (2012). Openness and innovation performance: are small firms different? (Working Paper No. 113). Coventry: Warwick Business School, CSME. Retrieved August 25, 2013, from https://www2. warwick.ac.uk/fac/soc/wbs/research/ei/research/ working_papers/working_paper_no._113.pdf.
Verdú-Jover, A.J., Lloréns-Montes, F.J., \& García-Morales, V. (2006). Environmentflexibility coalignment and performance: an analysis in large versus small firms. Journal of Small Business Management, 44(3), 334-349. doi:10.1111/j.1540-627X.2006.00175.x.

Verhees, F.J.H.M., \& Meulenberg, M.T.G. (2004). Market orientation, innovativeness, productinnovation, and performance in small firms. Journal of Small Business Management, 42(2), 134-154. doi:10.1111/j.1540-627X.2004.00102.x.

Walker, D.A. (2010). Costs of short-term credit for small and large firms. The Quarterly Review of Economics and Finance, 50(4), 485491. doi:10.1016/j.qref.2010.06.002.

Welsh, J.A., \& White, J.F. (1981) A small business is not a little big business. Harvard Business Review, 59(4), 18-32.

West, J., \& Drnevich, P.L. (2010). The effects of environmental uncertainty on young and small businesses. In Small Business, Entrepreneurship, and Economic Recovery Conference. Atlanta: Kauffman Foundation, Federal Reserve Bank. Retrieved August 27, 2013, from http://www.frbatlanta.org/documents/news/ conferences/10smallbusiness_WestDrnevich.pdf.

Westland, J. (2007). The project management life cycle: a complete step-by-step methodology for initiating, planning, executing \& closing a project successfully. Glasgow: Kogan Page Publishers.

Winston, E.R., \& Dologite, D.G. (1999). Achieving IT Infusion: a conceptual model for small businesses. Information Resources Management Journal, 12(1), 26-38.

Wymenga, P. et al. (2012). EU SMEs in 2012: at the crossroads. annual report on small and medium-sized enterprises in the EU, 2011/12. Rotterdam: Ecorys Nederland BV. Retrieved August 22, 2013, from http://ec.europa. eu/enterprise/policies/sme/facts-figuresanalysis/performance-review/files/supportingdocuments/2012/annual-report_en.pdf.

prof. Ing. Remigiusz Kozlowski, Ph.D. University of Lodz Faculty of Management Department of Logistics remigiuszk@poczta.fm

Ing. Marek Matejun, Ph.D. Lodz University of Technology Faculty of Organization and Management Department of Management marek@matejun.com 


\section{Abstract}

\section{CHARACTERISTIC FEATURES OF PROJECT MANAGEMENT IN SMALL AND MEDIUM-SIZED ENTERPRISES}

\section{Remigiusz Kozlowski, Marek Matejun}

The trend of specificity in studies on small and medium-sized enterprises management focuses on the search for characteristic qualitative and quantitative features distinguishing these entities from others, particularly from large enterprises. Research conducted within this trend may concern the general characteristics of small and medium-sized companies, as well as their functional characteristics connected with particular areas of management. One such area of growing importance for today's organizations is project management. This approach plays an important role in a dynamic, complex and uncertain environment, providing a response to accelerated competition, increased economic pressures, and rapid technological change. Use the project management by small and medium-sized enterprises enables cost reduction and facilitates the introduction of new products and services to the market, primarily including innovative solutions in response to individual and changing client requirements. However, project management should be implemented with consideration for the individual needs and possibilities of specific business entities, including SMEs. Taking this facts into consideration, the goal of the paper is to identify and evaluate select areas related to qualitative characteristics of project management in SMEs. The analysis refers to individual phases of a project life cycle, is of comparative nature, and is based on the results of studies conducted on a sample of 563 small and medium-sized enterprises and 334 large enterprises. The test of the difference between two population proportions was used to identify the areas of project management characteristic to SMEs statistically. Based on the study results, five research hypotheses have been verified concerning the basic goals, role of the owner, interorganizational cooperation, and limited formalization in the process of project management in small and medium-sized enterprises.

Key Words: Small and medium-sized enterprises, project management, large enterprises, entrepreneurship, comparative studies.

JEL Classification: L22, L25, L26, M00.

DOI: 10.15240/tul/001/2016-1-003 